\title{
2 Visual Story-Telling in Text and Image: The Nāga as Inhabitant of the Cosmic Ocean and the Netherworld
}

Just like many other ancient myths, the myth of the manifestation of the boar (varāha) has been reworked numerous times. It is retold in many texts, starting as early as the Vedas. ${ }^{1}$ It is the story of a god, first identified with Prajāpati ${ }^{2}$ and later with Viṣnu, ${ }^{3}$ who becomes a boar in order to rescue the earth from the subterranean regions. He dives into the cosmic ocean, lifts the earth with his tusk, ${ }^{4}$ and brings her back to her original spot. The myth is often told in a cosmogonical narrative framework and introduces the creation of the universe. ${ }^{5}$

The boar manifestation is also visualized in material art from at least the fifth century and possibly even earlier. Many of these Varāha images do not simply depict the god in his boar aspect, but provide a visual narration of the myth's climactic moment of Varāha lifting the earth. In this article, I explore the use of both text and image as means to narrate the Varāha myth. After providing an overview of relevant Varāha iconography, I focus on one particular element that is present in almost all images, but appears to have no textual counterpart: the inclusion of one or more Nāgas, ${ }^{6}$ mythical

1 For an overview of Sanskrit sources narrating the myth, see for example R. C. Agrawala, Solar Symbolism of the Boar: Yajña-varāha, an Interpretation (Varanasi: Devkumar, Prithivi Prakashan, 1963); Jan Gonda, Aspects of Early Viṣnuism, 2nd ed. (Delhi: Motilal Banarsidass, 1969); Wendy Doniger O'Flaherty, The Origins of Evil in Hindu Mythology (Berkeley: University of California Press, 1976); Dokter-Mersch, "Counter-Narratives: Parallel Themes in Śaiva and Vaișnava Mythology” (PhD diss., Leiden University, forthcoming).

2 Prajāpati is the main character in the Vedic texts and in the Rāmāyana.

3 Viṣnu is the main character in the Mahābhārata, Harivaṃśa, and the Purānasas.

4 This narrative component is relatively new, and the Harivamśa is one of the first available texts that incudes it as a standard element.

5 In the earliest sources, the universe is created for the first time (an event known as sarga, "creation"), whereas in the epics and the Purānas, the universe is recreated at the beginning of a new time cycle (known as pratisarga, "recreation"). The era of the manifestation of the boar is called Varāhakalpa; see Thomas Kintaert, "On the Role of the Lotus Leaf in South Asian Cosmography,” Wiener Zeitschrift für die Kunde Südasiens 54 (2011-2012): 92.

6 The number of Nāgas varies per image. For brevity's sake, I generally do not specify the number, only when I deal with a particular image.

Ә Open Access. () 2020 Sanne Dokter-Mersch, published by De Gruyter. (cc) BY-NC-ND This work is licensed under a Creative Commons Attribution-NonCommercial-NoDerivatives 4.0 International License.

https://doi.org/10.1515/9783110557176-003 
serpents ${ }^{7}$ that live in the Nāgaloka ("world of the Nāgas”), a subterranean, underwater world. ${ }^{8}$

For this, I include a text that heretofore has not been used in secondary literature: the Skandapurānna. ${ }^{9}$ It is a Saiva Purāna, ascribed to the sixth to seventh century ${ }^{10}$ and centering on Siva and his wife Pārvatī. It also incorporates a few Vaiṣnava myths that have been reworked into a Śaiva framework. The Varāha myth, with Viṣnu as the main character, has undergone several substantial changes as well. For example, the Skandapurāna version of the myth contains long battle descriptions, lively characterizations of the scenery, and an entirely new ending. ${ }^{11}$ Thanks to some of these additions and alterations, the Skandapurāna can shed new light on the presence of the Nāga in Varāha images. With the Skandapurāna in mind, I discuss some interpretations of the

7 For a study on Nāgas and references to other secondary literature, see Laurie Ann Cozad, "Nāgas," in Brill's Encyclopedia of Hinduism, vol. 6, Index, eds. Knut A. Jacobsen, Helene Basu, Angelika Malinar, and Vasudha Narayanan (Leiden: Brill, 2015), 72-80; Knut A. Jacobsen, "Sacred Animals," in Brill's Encyclopedia of Hinduism, vol. 1, Regions, Pilgrimages, Deities, eds. Knut A. Jacobsen, Helene Basu, Angelika Malinar, and Vasudha Narayanan (Leiden: Brill, 2009), 711-13.

8 The Nāgaloka is associated both with water and with the netherworld. For example, Cozad describes the Mahābhārata interpretation of the Nāgaloka as "a beautiful, bejeweled, underwater kingdom” (Cozad, "Nāgas," 78). Vogel and Kirfel rather situate (the world of) the Nāgas in the netherworld (pātāla), based on the Purānas; see J. Ph. Vogel, Indian Serpent-Lore or the Nāgas in Hindu Legend and Art (London: Arthur Probsthain, 1926), 30 and W. Kirfel, Die Kosmographie der Inder nach den Quellen dargestellt (Bonn: Kurt Schröder, 1920), 143-47.

9 Approximately half of the text (95 out of 183 chapters) has now been edited and the editing process is still ongoing. The entire Sanskrit text can be found in Bhațarāı’’s editio princeps: Kṛ̣nnaprasāda Bhaț̣arāī, ed., Skandapurāṇasya Ambikākhaṇḍh, Mahendraratnagranthamālā 2 (Kathmandu: Mahendrasaṃskrțaviśvavidyālayaḥ, 1988).

10 Yuko Yokochi, The Skandapurāna, vol. 3, Adhyāyas 34.1-61, 53-69. The Vindhyavāsini Cycle: Critical Edition with an Introduction \& Annotated English Synopsis (Brill: Leiden, 2013), 57-58.

11 The Skandapurāna version of the myth tells how Viṣnu becomes a boar in order to save the earth from the hands of the evil Hiranyāasṣa. Hiranyākșa is the king of the Daityas, who are the enemies of the gods, living in the netherworld called Rasātala. After a long fight, Viṣnu conquers Hiranyākșa and finds the earth kept hostage in Rasātala. He brings her back to her own abode, and his task is completed. Viṣnu would then normally leave his manifestation and resume his own form. However, in the Skandapurạna, he continues to live as a boar and it is Śiva's son Skanda, with the help of Śiva, who makes him return to his own body. As a reward, Śiva teaches Viṣnu the Pāśupatavrata, the highest Śaiva teaching. For a summary and study of this newly added part, see Phyllis Granoff, "Saving the Saviour: Siva and the Vaișnava Avatāras in the Early Skandapurāna," in Origin and Growth of the Purānic Text Corpus: With Special Reference to the Skandapurāna, ed. Hans T. Bakker (Delhi: Motilal Banarsidass, 2004), 111-138; Dokter-Mersch, “Counter-Narratives: Parallel Themes in Śaiva and Vaiṣnava Mythology.” 
Nāga suggested in previous studies, reexamine some Varāha images, and demonstrate how limited textual sources can still support the study of material art.

\section{Material Representation of the Varāha Myth}

There are two types of Varāha images: the zoomorphic boar, which is a depiction of Varāha in his animal form, and the anthropomorphic boar, which shows the deity with the head of a boar and the body of a man. Whether zoomorphic or anthropomorphic, the boar carries the earth, personified as a woman, and he is usually accompanied by a Nāga. The depiction is highly standardized, and only the details develop through time. For the present article, two phases in the development of Varāha iconography are worth highlighting: the Gupta-Vākāțaka period (fifth to early sixth century) and the period in which the Rāșțrakūtas, Cālukyas, and Pallavas were in power (mid-sixth to ninth century). ${ }^{12}$

Most Varāha images from the Gupta-Vākāțaka period were produced in Madhya Pradesh. ${ }^{13}$ The boar has two arms and wears a necklace and a rope

12 In "Viṣnu als Eber in Mythos und Bild," Gail identifies four phases of the development of Varāha images, with the Gupta-Vākāțaka period being preceded by the Kuṣāna period, when the production of Varāha images took place in and around Mathurā, Uttar Pradesh (second/third century). Gail discusses a rather exceptional exemplar from the Government Museum of Mathurā, earlier studied by Joshi; see Adalbert Gail, "Vișṇu als Eber in Mythos und Bild," in Beiträge zur Indienforschung: Ernst Waldschmidt zum 80. Geburtstag gewidmet, ed. H. Hartel (Berlin: Museum für Indische Kunst, 1977), 147-48 and Nilakanth Purushottam Joshi, "Kuṣāṇa Varāha Sculpture," Arts Asiatiques 12 (1965): 113-19. It concerns a panel with various figures, the one in the center having four arms, a thick neck, a necklace, and a rope around the waist, but his head is missing. To his right, there is a female figure draped on his shoulder. Based on a comparison with Varāha images, this indeed seems to be a depiction of Varāha. However, the fact that the figure has four arms appears exceptional for this period, for this detail only emerges in the period under the Rāșțakūtas, Cālukyas, and Pallavas (see below). The dating is based on an inscription at the bottom of the slab, identified by Joshi as second-century Brāhmī script (Joshi, "Kuṣāna Varāha Sculpture," 115). Another Varāha image that is assigned to the Kuṣāna period (third century) is kept at the Los Angeles County Museum of Art. Its head and other features are remarkably similar to the Udayagiri Varāha panel from the Gupta period, discussed below, so perhaps the dating should be slightly later. For the fourth phase in Gail's article, see note 25. Other studies on Varāha images, besides those mentioned below are Frederick M. Asher, The Art of Eastern India, 300-800 (Minneapolis: The University of Minnesota Press, 1980); Shanti Lal Nagar, Varāha in Indian Art, Culture and Literature (New Delhi: Aryan Books International, 1993); and Alexandra van der Geer, Animals in Stone: Indian Mammals Sculptured through Time (Leiden: Brill, 2008).

13 Gail, "Viṣnu als Eber in Mythos und Bild," 148 enumerates Badoh, Bhitargaon, Eran, Kutari, and Udayagiri. Joanna Gottfried Williams, The Art of Gupta India: Empire and Province (Princeton: 
around his waist. He stands in ālị̀ha position: one leg stretched behind and the other leg bent in front. ${ }^{14}$ This position is commonly used for figures with a bow and arrow, but can be applied more generally to heroic figures to express power. He generally stands on a Nāga with one foot. The earth, personified as a woman, clings to his right tusk and is sometimes supported by a lotus under her feet. One of the prime examples of this iconographical type is the Varāha panel in Udayagiri Cave 5, Madhya Pradesh, from the early fifth century (Figure 1). ${ }^{15}$ It is an impressive image, showing Varāha surrounded by dozens of gods, sages, and other beings. ${ }^{16}$

In the Gupta-Vākātaka period, the first zoomorphic exemplars appear as well. The boar stands on his four legs and his body is often covered with figures, which are probably deities and sages. The earth, personified as a woman, hangs from his tusk. The boar does not stand on a Nāga. Rather, if a Nāga is present, it coils freely between the boar's legs. Among the most impressive examples of this type is the zoomorphic boar from Eran, Madhya Pradesh. ${ }^{17}$ The image is decorated in an extremely detailed fashion. Numerous rows of small figures are shown. These are "sages (all bearded, with matted locks, holding holy-water jars)"18 and some may

Princeton University Press, 1982) adds Rājghat (p. 81), Nāchnā (p. 112), Pipariya (p. 116), and Gaḍhwa (p. 154). For Gaḍhwa, I have only found one Varāha image from the tenth century though; see, for instance, Stella Snead, Animals in four worlds: Sculptures from India (Chicago: University of Chicago Press, 1989), 38 and 144, plate 122. An overview of Varāha images in Madhya Pradesh is given in Haripriya Rangarajan, Varāha Images in Madhya Pradesh: An Iconographic Study (Mumbai: Somaiya Publications, 1997).

14 On this position, see, for example, Jitendra Nath Banerjea, The Development of Hindu Iconography, 2nd ed. (Calcutta: Calcutta University Press, 1956), 266-67; and V. Ganapati Sthapati, Indian Sculptures \& Iconography: Forms \& Measurements (Pondicherry: Sri Aurobindo Society, 2002), 64-65.

15 J. C. Harle, Gupta Sculpture: Indian Sculpture of the Fourth to the Sixth Centuries A.D. (Oxford: Clarendon Press, 1974), 35; Williams, The Art of Gupta India, 43; Michael Willis, The Archaeology of Hindu Ritual: Temples and the Establishment of the Gods (Cambridge: Cambridge University Press, 2009), 41.

16 Several attempts have been made in identifying the figures. See, for example, Debala Mitra, "Varāha-Cave of Udayagiri: An Iconographic Study," Journal of the Asiatic Society 5, nos. 3-4 (1963): 99-103; and Williams, The Art of Gupta India, 44. For an overview of studies on the Udayagiri panel, see Willis, The Archaeology of Hindu Ritual, 46-55.

17 According to Williams, the image is "executed close to 490 [. . .] or in 510" (Williams, The Art of Gupta India, 129). An extensive study of the Eran boar has been done in Catherine Becker, "Not Your Average Boar: The Colossal Varāha at Erāṇ, an Iconographic Innovation," Artibus Asiae 70, no. 1 (2010): 123-49.

18 Williams, The Art of Gupta India, 130. 


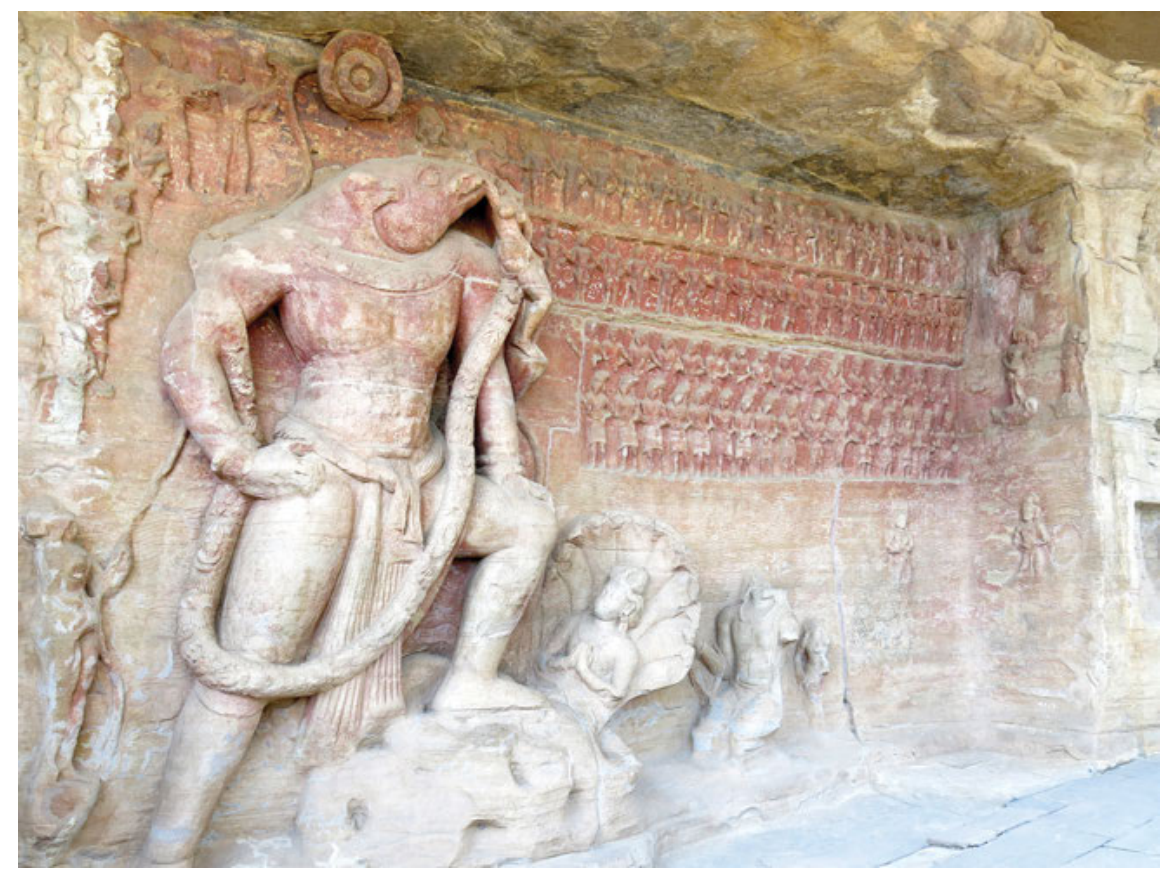

Figure 1: Varāha at Udayagiri Cave 5. Photo: Sanne Dokter-Mersch.

be identified as particular gods. ${ }^{19}$ Between the legs of the boar on the base, two Nāgas are sculpted. ${ }^{20}$

Although the production of Varāha images still continued in North India after the Gupta-Vākāțaka period, ${ }^{21}$ most images from the mid-sixth to the ninth century come from the area below the Narmadā River and were produced under the dynasties of the Rāṣțrakūṭas, Cāḷkyas, and Pallavas. ${ }^{22}$ The anthropomorphic

19 For example, Williams identifies Sūrya at the front, and the "small female figure above the tongue may aptly represent the personification of speech, Vāc” (Williams, The Art of Gupta India, 130).

20 According to Harle, Gupta Sculpture, 38, however, there are three serpents: one male and two females.

21 For instance, Rao describes an exemplar from Phalodi (Rajasthan); see T. A. Gopinatha Rao, Elements of Hindu Iconography, vol. 1, part 1 (Madras: The Law Printing House, 1914), 141. 22 For studies on Southern (Varāha) art and architecture from this period, see Aschwin Lippe, “Early Chālukya Icons,” Artibus Asiae 34, no. 4 (1972): 273-330 and Indian Medieval Sculpture (Amsterdam: North-Holland Publishing Company, 1978); K. V. Soundara Rajan, Cave Temples of the Deccan (New Delhi: Director General, Archaeological Survey of India, 1981); and George 
boars of this period ${ }^{23}$ can be recognized by their more explicit association with Viṣnu. Varāha is now depicted with four arms, two of them carrying a conch and a discus (cakra), Viṣnu's attributes. ${ }^{24}$ He stands in àlị̄ha position, often with his foot placed on one or two Nāgas. The position of the earth varies, but she is no longer clinging to the boar's tusk. Instead, she sits, for example, on the boar's elbow (Aihole Rāvanaphadi Temple) or stands on a lotus held in his hand (Bādāmi Cave 2). ${ }^{25}$

To summarize, there are several standard elements in the iconography of Varāha. The anthropomorphic boar is distinguished by the following elements:

1. The earth is personified as a woman;

2. She holds on to the boar's tusk in the Gupta-Vākātaka period and has a different, varying position in the next phase;

3. The boar stands in ālị̂ha position like a man; and

4. He generally stands on one or more Nāgas.

Zoomorphic boars can be recognized by the following standardized elements:

1. The earth is personified as a woman;

2. She holds on to the boar's tusk;

3. The boar stands on his four feet; and

4. One or more Nāgas coil freely between his legs.

Michell, Temple Architecture and Art of the Early Chalukyas: Badami, Mahakuta, Aihole, Pattadakal (New Delhi: Niyogi Books, 2014). Examples come from Ellora (Ravana ka Khai, Daśāvatara, Kailasa, and Milkmaid's Cave), Bādāmi (Caves 2 and 3), Aihole (Rāvaṇaphadi and Durgā Temple), Pațtadakal (Virupakșa Temple), and Māmallapuram (Varāha Cave).

23 Eliky Zannas, Khajuraho ('s-Gravenhage: Mouton \& Co Publishers, 1960), 132 notes that the production of zoomorphic boars appears only to have taken place in North India and never reached the Southern part.

24 This is not to say that the boar in the preceding phase cannot be identified with Viṣnu. Varāha images often appear in a Vaișnava context, such as a Viṣnu temple or in the vicinity of other Viṣnu images. For example, the Udayagiri Varāha panel is surrounded by other representations of Viṣnu.

25 Gail, "Viṣnu als Eber in Mythos und Bild,” 150 has identified one more phase after this period, in which the boar can have more than four arms and carries at least one additional attribute of Viṣnu, the club. The earth has various positions, although she usually sits on his elbow. Varāha stands in ālị̣ha position, placing his foot on one or two Nāgas or in some cases on a pedestal made of or held by Nāgas. 


\section{Text and Image}

Most of the standard iconographical components also appear in textual sources. The earth is often described as a woman, ${ }^{26}$ and even the detail that she holds on to the boar's tusk when he rescues her becomes a standard textual element. ${ }^{27}$ The description of the Skandapurāna in particular is remarkably similar to the way she is depicted in the Udayagiri panel. The text compares the earth hanging from the boar's tusk to dangling lotus fiber clinging to an elephant's tusk. ${ }^{28}$ This is highly comparable to the loosely hanging earth in Udayagiri. The similarities between text and image suggest that the authors and sculptors were aware of the same notion of how Varāha lifted the earth.

The possibility to portray Varāha as either anthropomorphic or zoomorphic is also available in both media. Whereas the anthropomorphic boar is preferred over the zoomorphic type for visual images, almost all texts describe the boar in his zoomorphic aspect as having four legs, a tail, and other animal characteristics. His limbs are usually inhabited by sacrificial elements and sacrificial deities, and sages reside between his hairs. ${ }^{29}$ Only a small number of texts depicts the boar as semihuman, semianimal, with Varāha having two arms, two feet, and the head of a boar. ${ }^{30}$

26 For example, the Viṣnupurāna qualifies the earth as a goddess: devī [. . .] vasumindharā, "goddess earth" (ViP 1.4.11a, d). The Harivamśa reports that the goddess earth is lifted by the boar: uddhṛtā prthivī devī, "the goddess earth is lifted" (HV app.1.42.188a).

27 For example, $H V$ 31.29:

damșțrayā yah samuddhṛtya lokānāṃ hitakāmyayā |

sahasraśîrșo devādiś cakāra jagatīm punaḥ || 29 ||

"Having lifted up [the earth (mahim in HV 31.28a)] with his tusk, for the welfare of the worlds, the thousand-headed one, who is the first of [all] gods, created the world again."

28 SP 108.14:

sa tāṃ daṃșțāànkure lagnāṃ vahan bhāti mrgeśvaraḥ|

viṣāṇalagnāṃ lambantīm mṛ̣ālị̣̄ gajarāẹ iva \|| 14 \||

"The lord of animals, carrying her, who had clung to the sprout of his tusk, was like a king of elephants [carrying] a dangling lotus fibre clinging to his tusk."

29 For a study on this "sacrificial boar" (yajñavarāha), see Agrawala, Solar Symbolism of the Boar, 1963.

30 The Skandapurāna is probably the first text that uses the term naravarāha, "man-boar." SP 97.11:

vārāham rūpam āsthāya na devatvaṃ na mānuṣam |

na ca tiryakṣu taj jātaṃ naravārāham asti vai || 11 || 
The only standard iconographical component that is usually not reflected in the textual versions of the Varāha myth is the Nāga. From the Mahābhārata to the Purāṇas, neither Nāgas in general nor one particular Nāga king appear at the moment that Varāha rescues the earth, nor in the Varāha myth as a whole. There is one exception, however: the Skandapurāna.

There are three references to Nāgas in the Skandapurāna. Two refer to Nāgas as a class of beings, and a third to Śeșa and other Nāga kings. The first reference is in the preamble of the myth. It is said that after a long battle with the gods, Hiranyākṣa, the king of the Daityas, wins and conquers the Triple World. He takes the earth with him to the pātāla ("netherworld") called Rasātala, where she is kept hostage. She is guarded by thousands of Daityas and is bound with nāgapāśas, "ropes that are Nāgas" (SP 95.13). ${ }^{31}$

This theme is again taken up at the conclusion of the myth, which is the second reference. As soon as Varāha kills Hiraṇyākșa, he goes out to find the earth. He discovers her in Rasātala, being tied down by Nāga lords, and releases her from them (SP 108.13). ${ }^{32}$ In neither passage are the Nāgas actual characters, but rather tools for Hiranyākșa to shackle the earth. Since Nāgas are known to live in pātāla, they are an understandable choice for this scene.

The third relevant passage explicitly mentions Śeșa and other Nāga kings. When the gods ask Viṣnu to kill Hiraṇyākṣa, he takes on the form of a boar and dives into the ocean toward Rasātala. During his descent, Varāha passes fabulous

"Having established a boar form that is neither divine, nor human, nor born among animals, he [i.e. Viṣnu] indeed becomes a man-boar."

The same idea is found in the Viṣnudharmottarapurạna, VDhP 1.53.14:

nrvarāho bhavișyāmi na devo na ca mānușaḥ |

tiryagrūpeṇa caivāham ghātayiṣyāmi taṃ tatah || 14 ||

"I will become a man-boar, [which is] not a god, nor a human being, but [joined] with an animal body; I will kill him then.”

31 SP 95.13:

tato rasātalam gatvā svapurasya samīpatah |

babandha nāgapāśais tām dușțām iva yathānganām || 13 ||

“Then, having gone to Rasātala, which is near his [i.e. Hiraṇyākṣa’s] own city, he [i.e. Hiraṇyākṣa] bound her [i.e. the earth] with ropes that are Nāgas, as if she were a sinful woman."

32 SP 108.13:

tato vidrārya nāgendrān pragṛhya pṛthivị̣̄ balāt |

jagāma daityān saṃdṛśya ratnāny ādāya sarvaśah || 13 \|

"Having rushed upon the Nāga lords, having forcefully taken the earth [from them], he [i.e. Varāha] went along, after seeing the Daityas and taking jewels from everywhere.” 
water creatures and places (SP 99.9ff.), like Hayaśiras (SP 99.13b), Bhogavatī (SP 99.13d), and the Milk Ocean (SP 99.16a). Then he passes the cities of several Nāga kings, such as those of Vāsuki, Takșaka, and Śeșa, the last called Ramañā, where he pauses for a short conversation (SP 99.17-22ab). ${ }^{33}$ Seșa is one of the primary kings of Nāgas and, in various other myths, one of Viṣnu's attendants. ${ }^{34}$ Varāha asks Śeșa not to pose any obstacles to what needs to be done for the world (SP 99.20cd). Śeșa replies that if Varāha wants, he could even do the task together with him (SP 99.21cd). However, Seșa does not reappear in the myth, and Viṣnu is able to complete the task himself.

This means that even in the Skandapurāna, where both Nāgas in general and Seșa in particular are mentioned, the mythical serpents do not play an essential role either in the story or at the moment that Varāha lifts the earth. Rather, they are introduced by the authors in order to enliven the scene. It is a narrative technique to textually visualize the place where the story is set at that

33 SP 99.18-23ab:

uṣitvā tatra so 'gacchat kankasya puram avyayam / vāsukeś ca puram prāpya takșakasya ca dhīmatah || 18 || tatạ̣ śeșasya deveśo viditām ramaṇām iti l ramyāṃ manojñāṃ divyāṃ ca svargād api ca tāṃ varām || 19 || śrutvānantaś ca tạ̣ rājā argheṇa ca sa pūjayat | praṇamya bahumānāc ca upāmantrayad avyayah || 20 || mahat kāryam idaṃ deva kartavyaṃ tridivaukasām / bhūyo vayaṃ tvayā sārdham karișyāma yadīcchasi || 21 || taṃ pūjayānaṃ madhuhā prìtyā paramayā yutaḥ | uvāca lokakāryasya na vighnaṃ kartum arhasi I mā ca kālo 'yam udyukto daityasya na bhaved iti || 22 || sanatkumāra uvāca | tato visrjya tạ̣ nāgaṃ rasātalam upāgamat |

"18: Having spent the night there [i.e. at the lake Kṣiroda], he [i.e. Varāha] went to the imperishable city of Kaṅka. Having reached the city of Vāsuki and of the wise Takṣaka, 19: he then [reached the city] of Śeșa, called Raman̄ā, which is beautiful, charming, divine and even better than heaven. 20: Having heard [about Varāha's arrival], king Ananta ["the one without end", i.e. Śeșa] honoured him with a guest-water. Having bowed down out of great respect, the imperishable one [i.e. Seșa] addressed [Varāha]. 21: 'This is a big task, oh god, that needs to be done by the heaven-dwellers. If you want, I can do it together with you. 22: The slayer of Madhu, filled with great affection, said to the worshipping one: 'Please do not create an obstacle for what needs to be done for the world. The Daitya's death should be undertaken.' 23: Sanatkumāra said: Having dismissed the Nāga then, he [i.e. Varāha] reached Rasātala.”

34 For example, Viṣnu sleeps on Seșa before the universe is recreated (see Gonda, Aspects of Early Viṣnuism, 89ff. and 151). 
moment, viz. in or near Rasātala. Since Nāgas are known to live in the subterranean regions, they are included as exemplary of pātāla. In other words, if we are looking for a Nāga as an active player in the story, then even the Skandapurāna cannot serve as the textual counterpart of the Nāga in the Varāha images. ${ }^{35}$ How should the iconographical Nāga then be interpreted?

\section{Alternative Interpretations}

One possibility is that the presence of a Nāga is only a convention among sculptors and not among authors. According to the iconographic sections (pratimālakșaṇa, "characteristics of images") of several Sanskrit sources, a Nāga is indeed required. For example, the Viṣnudharmottarapurāna has a long passage on what Varāha images should look like, ${ }^{36}$ and the Nāga king Seșa is to be included. ${ }^{37}$ The author of this part of the Viṣnudharmottarapurāna does not explain why he understands the Nāga to be Śeșa, and this is probably his own interpretation. Since Viṣnu is associated with Śeșa and a Nāga is present in almost all Varāha images, it would seem logical to identify the Nāga as Śeșa. Although this association could have been the reasoning of the sculptors as well, there is no textual evidence for this.

Still, the Nāga is often taken to be Seșa in the secondary literature as well. ${ }^{38}$ The fact that Śeșa does not play a role in the Varāha myth is usually neglected,

35 An instance in which this is the case is the story of the churning of the Milk Ocean. When Viṣnu manifests himself as a turtle (kūrma) to help the gods churn nectar from the Milk Ocean, the Nāga king Vāsuki assists them. He has a key role in the story and is visualized as such in material art (for example, in Pāwāya; Williams, The Art of Gupta India, 53-55).

36 The Agnipurāna (AgP 1.49.2-3) and the Matsyapurāna (MtP 260.28-30ab) have similar descriptions.

37 VDhP 3.79.2ab, 4cd:

nṛvarāho 'thavā kāryaḥ śeșoparigatah prabhuḥ | 2 |

[. . .] ālị̄hasthānasaṃsthānas tatprșțhe bhagavān bhavet || 4 \||

"Alternatively, a man-boar should be made. The lord should stand on Śeșa. [. . .] The lord should be standing on his back in ālị̈ha position."

38 For example, Banerjea writes about the Varāha image in Udayagiri: "The colossal twoarmed Varāha Avatāra treads with his left foot on the coils of Ādiśeșa” (Banerjea, The Development of Hindu Iconography, 414). As Rao remarks on a Varāha image in Bādāmi, "At the foot of Varāha is Ādiśēsha's wife; on the proper left is standing erect Ādiśēsha himself" (Rao, Elements of Hindu Iconography, 140). Lippe discusses the Dūrga temple at Aihole as follows: "Varāha once more steps on the coil of the adoring king of the ocean who is placed to the right, with his queen” (Lippe "Early Chālukya Icons,” 281). 
and an alternative explanation for his presence is not provided. However, there are a few exceptions to this.

The first is Bakker's study on the fifth-century zoomorphic boar from Rāmagiri (Ramtek Hill), Mahārāșțra. Between the legs of the boar, a Nāga is freely moving around. According to Bakker, the Nāga is "the cosmic serpent Śeșa, who supports the universe and serves as a prop for Varāha."39 This refers to a story in the Mahābhärata (MBh 1.32), in which Brahmā assigns the task of always carrying the earth to Seșa. This is why Śeșa lives in the subterranean regions, with the earth on top of him. ${ }^{40}$ If we take Śeșa to represent the earth's base, then the place to which Varāha brings the earth back - svasthāna, "her own abode" - could possibly refer to Seșa. ${ }^{41}$ From the perspective of the position of the Nāga in this and other zoomorphic Varāha images, the interpretation seems fitting. However, the position of the Nāga in the anthropomorphic images is significantly different: instead of coiling around freely, the mythical serpent is stepped upon by Varāha, which suggests that Varāha suppresses the animal. Since the anthropomorphic type outnumbers

39 Hans T. Bakker, The Vākāțakas: An Essay in Hindu Iconology (Groningen: Egbert Forsten, 1997), 138.

$40 M B h$ 1.32.24:

adho bhūmer vasaty evaṃ nāgo 'nantah pratāpavān |

dhārayan vasudhām ekaḥ śāsanād brahmaṇo vibhuh || 24 ||

"So the majestic Snake Ananta dwells underneath the ground, ubiquitous, holding good earth up at the bidding of Brahmā”; translation from J. A. B. van Buitenen. The Mahābhārata: 1. The Book of the Beginning (Chicago: University of Chicago Press, 1973), 93.

41 Usually, only the word svasthāna is used (MBh 12.326.71cd-72, HV app.1.42.183-84, VāP 6.25, and SP 108.16). The Viṣnupurāna, however, makes explicit that the earth is put on the great ocean, mahārnava (ViP 1.4.45). To the best of my knowledge, the Padmapurāna is the only text that, in the Varāha myth, qualifies Śeșa as the place to which the earth is returned.

PdP Uttarakhaṇda 264.18:

patitām dharaṇim dṛșțvā daṃștrayoddhṛtya pūrvavat | saṃsthāpya dhārayāmāsa śeșe kūrmavapus tadā || $18 \|$

"Having seen the earth fallen down, having lifted [her] up with his tusk like before, having raised [her], he, having the form of a turtle, then carried [her] on Śeșa.”

The passage tells us that Viṣnu raised the earth in the form of a boar, and in the form of a turtle, he put her back on Śeșa. If the Nāga in the Varāha images would indeed be Śeșa as the home of the earth, then the Padmapurāna would still not be a textual parallel, because it is Viṣnu in the form of Kūrma who puts the earth back. The combination of the two animals is in any case "rather confusing. As is well known, Viṣnu assumed the form of the tortoise in the second incarnation to give support to the mountain Mandara which served as a churning rod for gods who wanted to acquire Amṛta from the Milky Ocean”; see N. A. Deshpande, The Padmapurāna, part 9 (Delhi: Motilal Banarsidass, 1991), 3197. 
the zoomorphic one, there appears still to be a discrepancy between text and image. ${ }^{42}$

Another interpretation worth mentioning is Willis's study of the Udayagiri Varāha panel. He describes the boar as "in triumphant control of the waters for he holds down their personification, the serpent king, with his foot." ${ }^{43}$ He later specifies the waters as ekārnava, "single ocean." "I4 In other words, according to Willis, the Nāga, identified as Śeșa, does not refer to an idea in a different myth, but rather to a metaphorical idea: the Nāga as a representative of the cosmic ocean. $^{45}$

A similar approach to the Nāga has been suggested by Gail. Without specifying the Nāga by name, he argues that the mythical being is a representative of the netherworld. ${ }^{46}$

This interpretation brings us back to the Skandapurāna. After all, as demonstrated above, the insertion of the scenes with Nāgas in this text is a narrative technique to visualize the place where the scene takes place. The Nāgas are added as representatives of the netherworld. If Nāgas can indeed stand for a particular cosmic realm (whether it be the cosmic ocean or the netherworld), both in texts and in iconography, let us revisit the textual description of the moment that Varāha lifts the earth from the subterranean regions and see whether the place of rescue found in the texts corresponds to the place where the Nāgas live and thus to the Nāga in Varāha images.

42 Additionally, the Rāmagiri boar and its accompanying Nāga can be interpreted as a political allegory. Rudrasena II, who erected the image, was married to Prabhāvatī Guptā, affiliated with the Gupta kingdom and the Nāga kingdom (Bakker, The Vākāțakas, 15-16). The Rāmagiri Varāha then stands for the Vākāțaka rulers and the Nāga for their special relationship with the Nāga court. The image celebrates the union of these two royal families.

43 Willis, The Archaeology of Hindu Ritual, 45.

44 Willis, The Archaeology of Hindu Ritual, 59.

45 Seșa as the personification of the cosmic ocean is mentioned earlier by Zimmer: "Shesha, the serpent Endless, representative of the cosmic waters, who is the source of all water whatsoever, is his [i.e. Viṣnu's] animal representative”; see Heinrich Zimmer, Myths and Symbols in Indian Art and Civilization (New York: Pantheon Books, 1946), 76.

Additionally, the Udayagiri Varāha panel is probably also a political allegory. According to Willis and several scholars before him (for an overview, see Willis, The Archaeology of Hindu Ritual, 46-55), Varāha stands for Samudragupta and "the prominent nāga figure on which the Varāha places his foot [. . . ] is a justification for Samudragupta's well-known suppression of the Nāga kings who rose up against him in the fourth century" (Willis, The Archaeology of Hindu Ritual, 59).

46 "Ein Nāga oder Nāgapaar als Vertreter der Unterwelt zu Füßen des Mannebers oder Ebers gehört [. . . ] zu den charakteristischen Bestandteilen späteren Kompositionen” (Gail, "Viṣṇu als Eber in Mythos und Bild," 174). 


\section{Place of Rescue}

The place of rescue does not remain the same place over time, and a development in two phases can be observed. First, in the Vedic sources, the Mahäbhärata, and one early Harivamiśa passage, ${ }^{47}$ Varāha rescues the earth from water. For example, the Taittirīya Saṃhita reads in its Varāha episode āpo [. . .] salilam, "water [. . .] ocean" (TS 7.1.5.1.1); ${ }^{48}$ the Mahābhārata reads samudrāt, "from the ocean" (MBh 3.100.19b); ${ }^{49}$ and in the main text of the critical edition of the Harivamsśa, the term ekârnava, "single ocean" is used. ${ }^{50}$ In each example, the

47 The critical edition of the Harivamśa is divided into two parts: the "critical text," in Parashuram Lakshman Vaidya, The Harivamsa, Being the Khila or Supplement to the Mahābhärata, vol. 1, Critical Text (Poona: Bhandarkar Oriental Research Institute, 1969); and the "appendices," considered to have been added later, in Parashuram Lakshman Vaidya, The Harivamsa, Being the Khila or Supplement to the Mahābhārata, vol. 2, Appendices (Poona: Bhandarkar Oriental Research Institute, 1971). The division is based on manuscript evidence. If a passage is found in "the extremes" (Vaidya, The Harivamsa, 1:xxiv), i.e. the most divergent manuscripts from the northwestern, northeastern, and southern manuscript groups, then it is placed in the "critical text." Although this division and difference in dating may be true for a number of the appendices, there is reasonable doubt whether this also holds for three manifestation myths of Viṣnu: Varāha (appendix 1.42), Narasiṃha ("man-lion,” appendix 1.42A), and Vāmana ("dwarf," appendix 1.42B). For a discussion on this topic, see Vaidya, The Harivamsa, 1: xxxiv; John Brockington, The Sanskrit Epics (Leiden: Brill, 1998), 320; Marcelle Saindon, Trois Manifestations de Vishnu, le Sanglier, l'Homme-Lion, le Nain: Les récits du Harivamsha (Paris: Presses de l'université Paris-Sorbonne, 2009), 22ff.

48 TS 7.1.5.1.1-5:

âpo vâ idám ágre salilám āsît | tásmin prajâpatir vāyúr bhūtvâcarat | sá imầm apaśyat | tâm varāhó bhūtvâharat | tâṃ viśvákarmā bhūtvâ vyàmārț |

"This was in the beginning the waters, the ocean. In it Prajāpati becoming the wind moved. He saw her, and becoming a boar he seized her. Her, becoming Viçvakarma, he wiped"; translation from Arthur Berriedale Keith, trans., The Veda of the Black Yajus School, Entitled Taittiriya Sanhita, part 2, Kāṇdas IV-VII (Reprint, Delhi: Motilal Banarsidass, 1967), 560.

49 MBh 3.100.19:

tvayā bhümiḥ purā naștā samudrāt puṣkarekṣaṇa |

vārāhaṃ rūpam āsthāya jagadarthe samuddhṛtā || $19 \|$

"When of yore the earth was lost, lotus-eyed God, thou didst rescue it from the ocean, assuming the form of a boar, for the sake of the world"; translation from J. A. B. van Buitenen, The Mahābhärata: 2. The Book of the Assembly Hall, 3. The Book of the Forest (Chicago: University of Chicago Press, 1975), 420.

50 HV 31.HV 31.28-29:

mahīm sāgaraparyantāṃ saśailavanakānanām |

ekārṇavajale bhrașțām ekārṇavagatị̣ prabhuḥ || 28 || 
water should be understood as cosmic or primordial water because these versions of the myth appear in cosmogonical sections dealing with the creation of the universe. ${ }^{51}$

The term ekärnava continues to be used in later versions of the myths the second phase - but the Rasātala is added as the final place of rescue. The Harivamśa appears to be right at the intersection of this development, for in the long version of the Varāha myth, relegated to the appendix of the critical edition ( $H V$ app.1.42), a combination of both elements is found. ${ }^{52}$ The boar first dives into the ocean and then continues his journey down to Rasātala, to which the earth had sunk and where the actual rescue takes place. This combination becomes the standard in various Purānas. ${ }^{53}$

daṃștrayā yaḥ samuddhṛtya lokānāṃ hitakāmyayā |

sahasraśīrșo devādiś cakāra jagatīm punaḥ || 29 ||

"The lord, going to the single ocean, having lifted up the earth, who is surrounded by the oceans [and covered] with mountains, forests and groves, who had fallen into the water of the single ocean, with his fang for the welfare of the worlds, the thousand-headed one, who is the first of [all] gods, created the world again."

51 Slaje shows that a combination of salila and agre in Vedic sources indicates the primordial salt water; see Walter Slaje, "Water and Salt (III): An Analysis and New Translation of the Yājñavalkya-Maitreyī Dialogue,” Indo-Iranian Journal 45 (2002): 218, n. 38.

$52 H V$ app.1.42.150-52 (water):

tato mahātmā manasā divyạ̣ rūpam acintayat | 150 |

kiṃ nu rūpam ahaṃ krtvā uddharāmi vasuṃdharām || 151 ||

jale nimagnāṃ dharaṇị̣ yenāhaṃ vai samuddhare | 152 |

"Then the great soul thought about a divine body with his mind: 'What kind of body shall I make, with which I will raise the earth, the world, who had sunk into the water [and with which] I shall lift [her]?””

$H V$ app.1.42.181-82 (Rasātala):

rasātalatale magnāṃ rasātalatalaṃ gatạ̣ | 181 |

prabhur lokahitārthāya daṃștrāgreṇojjahāra gām || 182 ||

"The lord, who had gone to the bottom of Rasātala, lifted up the earth, who had sunk to the bottom of Rasātala, with his tusk for the welfare of the world."

53 The combination is found, for example, in the Vãyupurāna.

VāP 6.2 (single ocean):

ekārnave tadā tasmin nașțe sthāvarajañgame |

tadā samabhavad brahma sahasrākșaḥ sahasrapāt || 2 ||

"When [the earth with] the moving and unmoving had disappeared into that single ocean, then Brahmā, the thousand-eyed, the thousand-footed, arose." 
A comparison between the Harivamśa passage in the first phase (HV 31.28-29) and the texts of the second phase shows that often the same standardized verse is used. It reports that Viṣnu lifts the earth, who "has sunk" or "is lost," with his tusk for the sake of the world. The only element that changes structurally from the first Harivamśa passage in the former phase to the Purānas and the Harivamśa passage in the latter phase is the place of rescue: from ekārnava to Rasātala. ${ }^{54}$

\section{The Cosmos Visualized}

Is this development also visible in the iconography of Varāha? Does the Nāga represent the cosmic ocean in one image (as proposed by Willis) and Rasātala in the other (as proposed in more general terms by Gail)? To answer this question, I have chosen anthropomorphic boar images - because the element of suppression is absent in the zoomorphic exemplars - which moreover have enough additional details that can show in which realm the Nāga and the rest of the image are located.

The first relevant image is the anthropomorphic boar of Udayagiri Cave 5 (See Figure 1). The panel is divided into two parts, each representing a different realm. The lower half shows various traces of the ocean. The rippling, horizontal carvings are waves, and a few lotuses are still visible. The upper part is carved with numerous gods, who represent heaven. The Udayagiri panel hence depicts a division between heaven and the cosmic ocean.

The other relevant images appear in cave temples sponsored by the Rāștrakūṭas, Cālukyas, and Pallavas. At least five panels from this period display many details of the setting of Varāha's heroic deed. The first is the Māmallapuram Varāha Cave panel, which is divided into two parts (Figure 2). In the lower part, we find the Nāga under the foot of Varāha, surrounded by swirls and lotuses, which suggest the ocean. The figures surrounding Varāha on the upper part of the

VāP 6.24 (Rasātala):

rasātalatale magnāṃ rasātalatale gatām | prabhur lokahitārtāya damsștrayābhyujjahāra gām || 24 ||

"The lord lifted up the earth, who had sunk to the bottom of Rasātala, who had gone to the bottom of Rasātala, with his tusk for the welfare of the world."

54 Compare ekārṇavajale bhraștām ekārṇavagatị prabhuḥ (HV 31.28cd) and rasātalatale magnām rasātalatalaṃ gatạ̣ (HV app.1.42.181). 


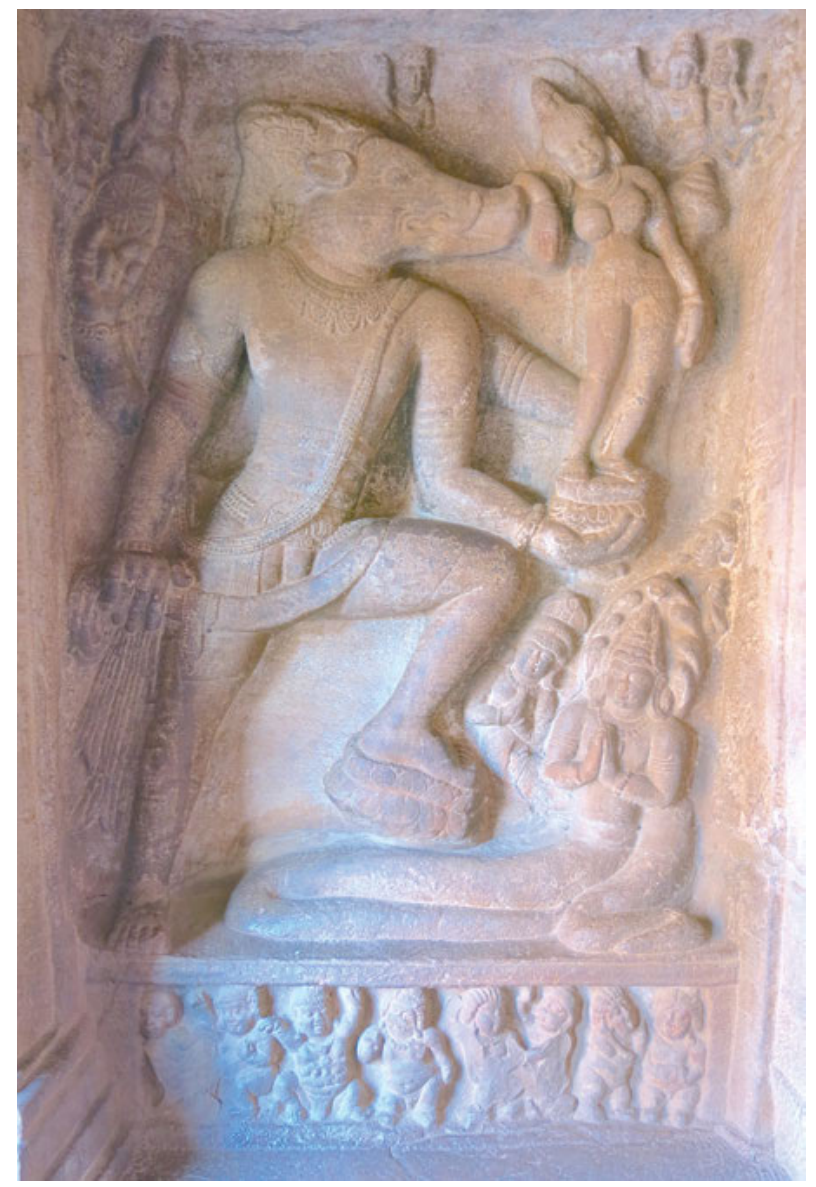

Figure 2: Varāha at Māmallapuram Varāha Cave. Photo: American Institute of Indian Studies.

panel are celestial beings, ${ }^{55}$ representing heaven. The Māmallapuram panel therefore also visualizes a division between heaven and the cosmic ocean.

The distribution is less clear in the case of Bādāmi Cave 2 (Figure 3). The only element that could indicate the ocean is the lotus on which Varāha puts his foot and which rests on the coil of a Nāga. However, according to Boner, it is significant that the Nāgas' tails are not coiled: "This may be another way of signifying

55 Boner identifies the celestial beings as the sun and the moon, Brahmā, and the Yogins from the Janaloka; see Alice Boner, Principles of Composition in Hindu Sculpture (Leiden: E. J. Brill, 1962), 132. She concludes that "Varāha lifts Bhūdevĩ from the depth of the abyss to the regions of Sun and Moon” (Boner, Principles of Composition, 138). 


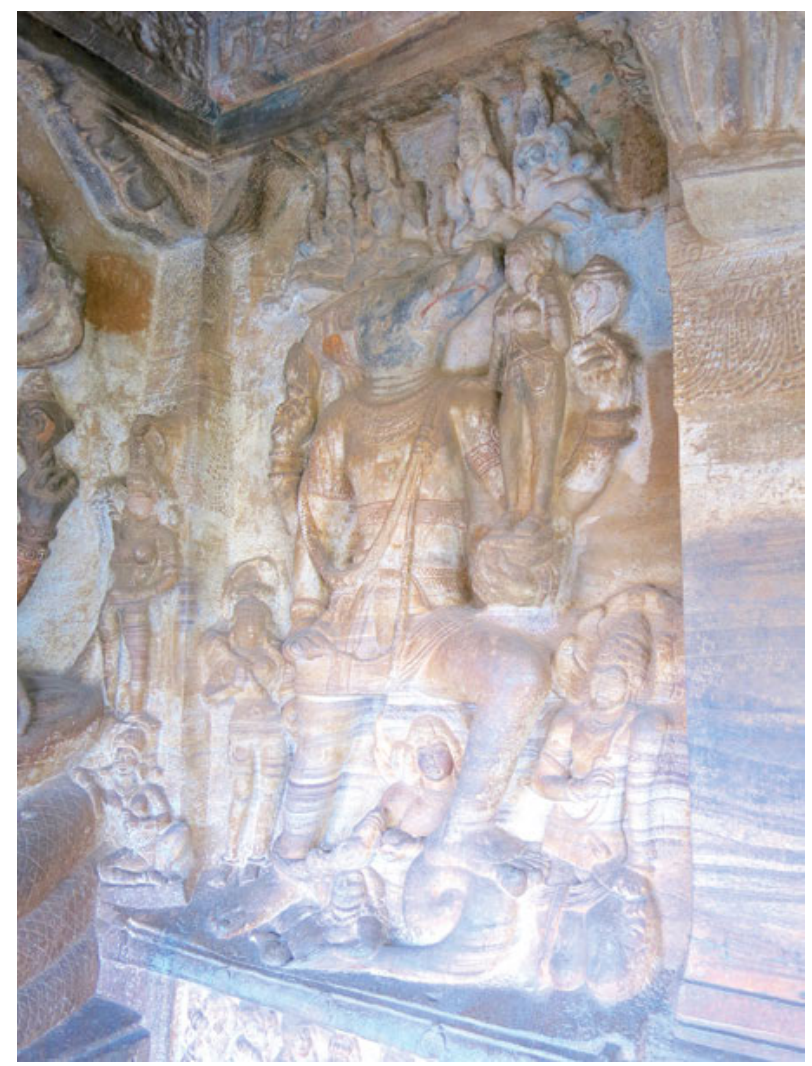

Figure 3: Varāha at Bādāmi Cave 2. Photo: Elizabeth A. Cecil.

the horizontal extension of the Waters." ${ }^{56}$ The upper part is probably heaven, suggested by the flying couples above Varāha's head, usually interpreted as vidyādharas. ${ }^{57}$ These "wisdom carriers," however, may also function as worshippers of Vișnu.

The bottom part of the Varāha panel at Ellora Cave 14 (Ravana ka Khai, Figure 4) shows no sign of either the cosmic ocean or the netherworld. The upper part, on the other hand, has several elements pointing to heaven.

56 Boner, Principles of Composition, 124.

57 For a definition of vidyādhara, see, for example, Boner, Principles of Composition in Hindu Sculpture, 259; Sthapati, Indian Sculptures \& Iconography, 435-36. Compare Banerjea's identifying the flying beings in Bādāmi Cave 2 as "gandharvas" (Banerjea, The Development of Hindu Iconography, 16). 


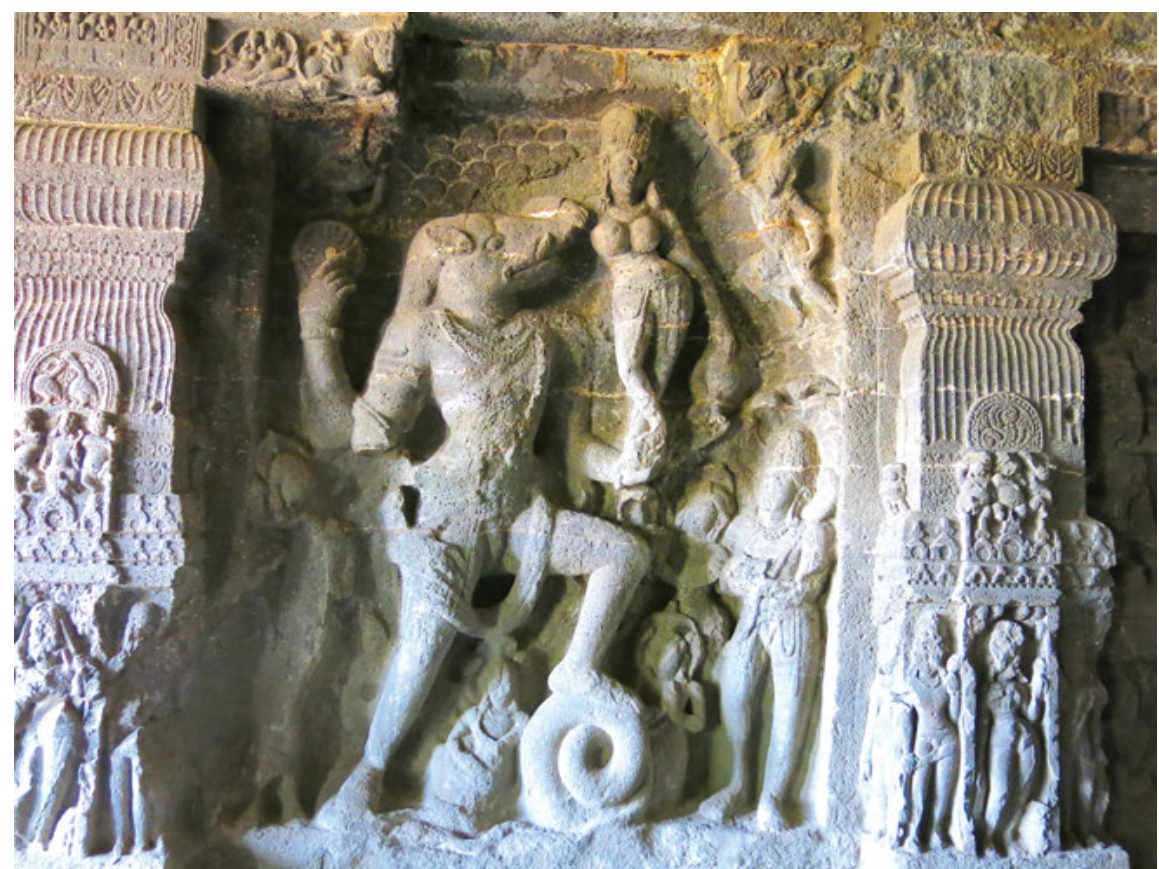

Figure 4: Ellora Cave 14 (Ravana ka Khai). Photo: Elizabeth A. Cecil.

There are flying figures in the upper corners, and above Varāha's head there are "conventional representations of the heavens in the form of semi-circular cloud patterns." ${ }^{58}$ Although there are indications that the upper part is heaven, it is not possible to identify the lower part. ${ }^{59}$

The final two panels are Bādāmi Cave 3 (Figure 5) and Ellora Cave 16 (Kailasa, Figure 6). These however show details on the lower part of the panel. The upper part of Bādāmi Cave 3 merely shows two pairs of flying celestials above Varāha's head, and there is no further indication of heaven. At the bottom of the panel, there are two Nāgas and a male figure between the legs of Varāha. His lower left arm rests on the tip of the Nāga's coil and his right hand holds on to

58 Soundara Rajan, Cave Temples of the Deccan, 110.

59 According to Boner, however, the lower part can be classified as the ocean. The madhyaprastha, the "central horizontal middle-line in a diagram" (Boner, Principles of Composition, 253), "divides the lower worlds of the waters from the upper worlds of earth and heaven," and the goddess earth "carries her head victoriously in the region of the clouds, which represent Svārloka ["heaven"]” (Boner, Principles of Composition, 114). 


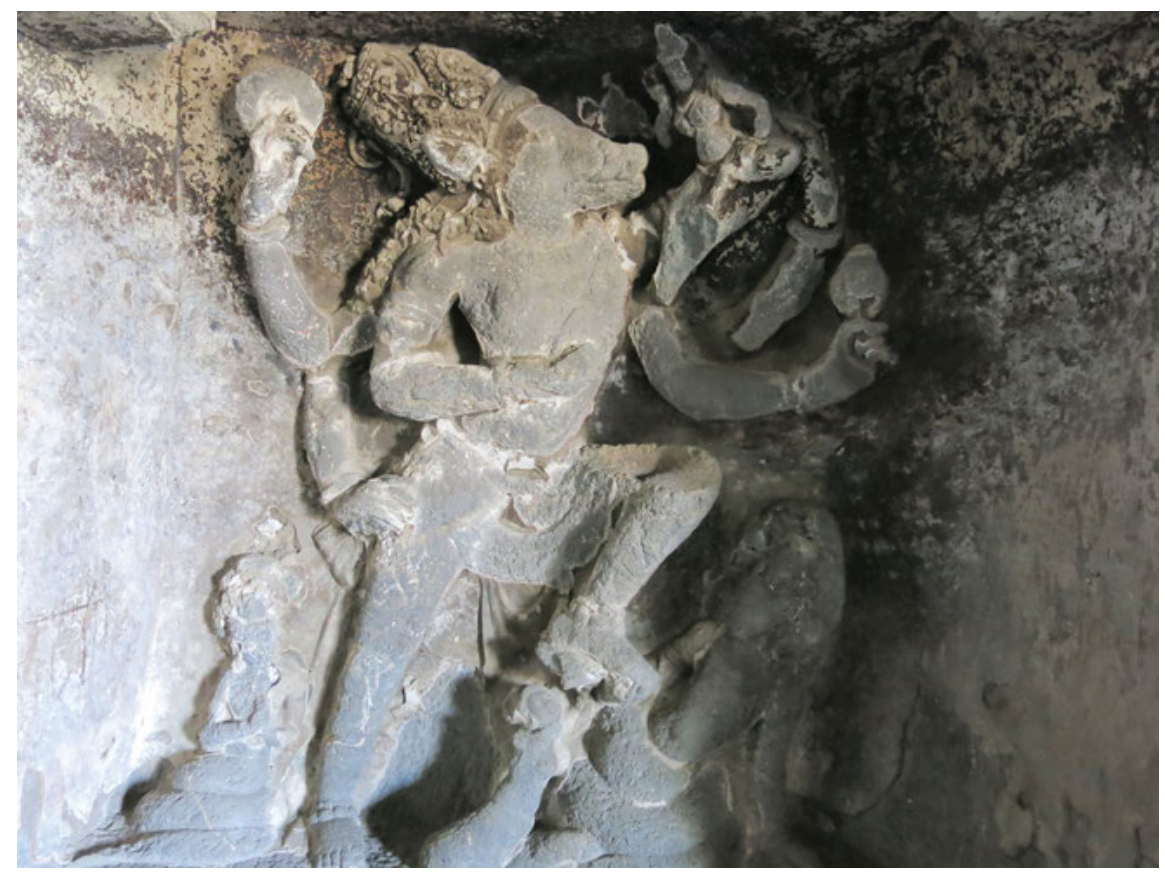

Figure 5: Bādāmi Cave 3. Photo: Elizabeth A. Cecil.

Varāha's sacrificial cord. He has no coils, so it cannot be a Nāga. ${ }^{60}$ Several other interpretations have been given, such as a "figure of a dwarf, lying on the ground,"61 "a gana in the nether waters,"62 or "a dwarf between the legs"; in fact, "Hiranyākșa is caught in the flowing wash of nāgas and garlands."63 Although the figure resembles the gaṇas in the frieze below the Varāha panel,

60 According to Boner, the figure is, in fact, a "small Nāga floating between his [i.e. the boar's] legs." She takes this lower space to be "the Nāga-world, the Primordial Waters," with two realms on top of it. One of these "is the middle region, the antarikșa, which, in contrast to the nether worlds, has an atmosphere and breathing space, and in which the sight becomes free to the heavenly regions, where the Vidyādharas, the holders of divine knowledge, dwell" (Boner, Principles of Composition, 116; 119).

61 R. D. Banerji, Memoirs of the Archaeological Survey of India, no. 25, Basreliefs of Badami (Calcutta: Government of India Central Publication Branch, 1928), 36.

62 Soundara Rajan, Cave Temples of the Deccan, 68.

63 Preeti Sharma, "The Meaning and Symbolism of Varāha Motif: With Special Reference to the Chālukyan Rock-cut Caves at Bādāmī,” Journal of History \& Social Sciences 1, no. 1 (July-December 2010), http://jhss.org/archivearticleview.php?artid=94. 


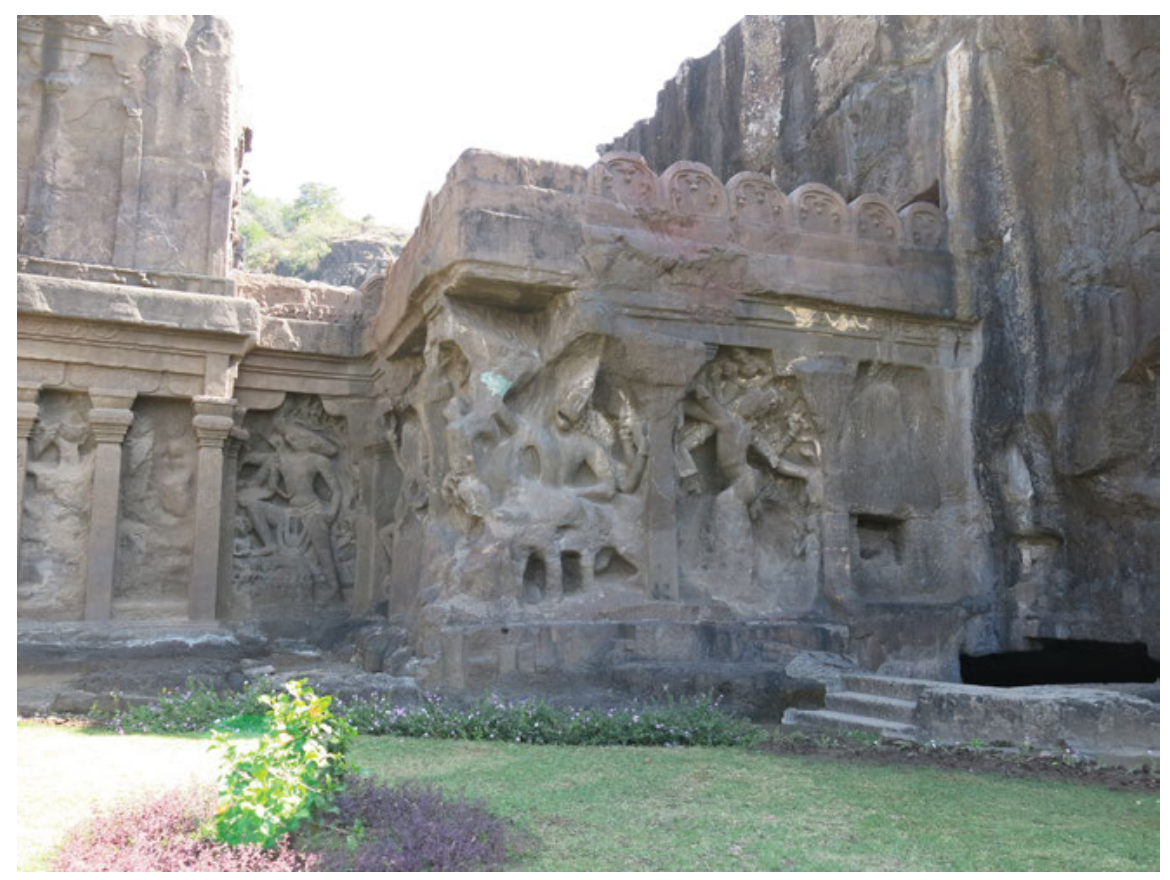

Figure 6: Ellora Cave 16 (Kailasa). Photo: Elizabeth A. Cecil.

the ocean is not a common place for a gana. I am not convinced by the identification of Hiranyākșa either, for, although the Daitya king is closely related to the Varāha myth, the figure does not display any signs of Hiranyaākșa in particular. Despite the fact that the panel has various figures in the bottom part, it is not possible to determine where they are located because it is not clear who they are.

The Varāha image in Ellora Cave 16 is partly damaged, which complicates its interpretation. However, it may be the first sculpture showing heaven and the netherworld. Heaven appears to be intended through the presence of the celestial beings flying above Varāha's head, but there are no further details referring to heaven. In the lower part of the image, a Nāga is present, but he is not stepped upon by Varāha. Instead, Varāha places his foot on a pedestal, which is made clearly distinct from the rest of the image by the coarse line under the right foot of Varāha. The pedestal is decorated with at least eight figures. Due to damage to this section, it is difficult to identify them. The two creatures on the left may be Nāgas, if the halolike circles behind their heads are snake hoods and if the elongated bodies flowing below their torsos are their 
coils. There is one figure next to them that has a similar shape in head and torso. The figures on the right seem to be kneeling before the three on the left. Since the pedestal is separated from the rest of the image, it looks like a separate world, from which Varāha arises and which he presses down with his foot. If the artist had the ocean in mind, then he would probably have sculpted the bottom part differently, namely more clearly as water. The artist instead seems to have had another realm in mind, which by the time of this Ellora cave (eighth century ${ }^{64}$ could very well have been pätāla.

\section{Conclusion}

I began this study by showing that there is great correspondence between, on the one hand, the textual description of the Varāha myth in general and the moment that Varāha rescues the earth in particular, and their iconographic representation on the other hand. I have noted one exception. Whereas one of the standard elements of the Varāha images is the presence of a Nāga, there is no mention of any Nāga in most of the texts. The Skandapurāna is probably the only text that mentions Nāgas in general and some Nāga kings in particular (especially Śeșa), but it does not ascribe the mythical serpents any particular role in the story. The text, therefore, does not provide a textual counterpart of the Nāga in the Varāha images. However, what the Skandapurāna does demonstrate is that Nāgas can represent a certain realm of the cosmos, viz. a part of the netherworld, (near) the pātāla called Rasātala. Taking Nāgas as exemplary of a part of the cosmos has helped in identifying the Nāga in Varāha iconography, as well as in finding a textual counterpart after all: the place from which Varāha rescues the earth.

In almost all the texts, the description of the moment that Varāha lifts the earth contains several standard elements, including the place of rescue. The place develops from the cosmic ocean (in Vedic sources and early epic-Purāṇic texts) to Rasātala (in later epic and Purāṇic texts). If we take the Nāga to represent one of these two places in Varāha iconography, the place of rescue is then visualized. In material art, there appears to be a clear preference for the cosmic ocean, for the images showing water greatly outnumber the instances in which

64 "The Kailāsa temple was the result of the munificence of Rāṣtrakūṭa Kṛṣna I (A.D. 756-773) and was named after him as Kṛṣnēśvara.” Michael Meister, Encyclopaedia of Indian Temple Architecture: South India - Upper Drāvị̣adēśa - Early Phase, A.D. 550 - 1075 (New Delhi: American Institute of Indian Studies, 1986), 111. 
the netherworld is depicted. In fact, only Ellora Cave 16 seems to represent pātāla, for it is clearly distinct from the other images in the way it depicts its bottom part. If the sculptor would have wanted to show an underwater world, he would probably have done this differently.

To conclude, even though the depiction of a Nāga seemed to point to a discrepancy with the textual version of the Varāha myth, this problem is solved when we construe the Nāga as a representative of a cosmic realm. This appears to have been a cultural idiom in both text and image; the two forms of media therefore do not seem so different after all.

\section{Abbreviations}

$\begin{array}{ll}\text { AgP } & \text { Agnipurāṇa } \\ H V & \text { Harivaḿ̧a } \\ M B h & \text { Mahābhārata } \\ \text { MtP } & \text { Matsyapurāṇa } \\ P d P & \text { Padmapurāṇa } \\ S P & \text { Skandapurāṇa } \\ T S & \text { Taittirīya Saṃhitā } \\ V \bar{a} P & \text { Vāyupurāṇa } \\ V D h P & \text { Viṣnudharmottarapurāṇa } \\ \text { ViP } & \text { Vișṇupurāṇa }\end{array}$

\section{Bibliography}

Agrawala, R. C. Solar Symbolism of the Boar: Yajña-varāha, an Interpretation. Varanasi: Devkumar, Prithivi Prakashan, 1963.

Asher, Frederick M. The Art of Eastern India, 300-800. Minneapolis: The University of Minnesota Press, 1980.

Bakker, Hans T. The Vākātakas: An Essay in Hindu Iconology. Groningen: Egbert Forsten, 1997. Banerjea, Jitendra Nath. The Development of Hindu Iconography, 2nd ed. Calcutta: Calcutta University Press, 1956.

Banerji, R. D. Memoirs of the Archaeological Survey of India. No. 25, Basreliefs of Badami. Calcutta: Government of India Central Publication Branch, 1928.

Becker, Catherine. "Not Your Average Boar: The Colossal Varāha at Erāṇ, an Iconographic Innovation." Artibus Asiae 70, no. 1 (2010): 123-49.

Bhațțarāī, Kṛ̣ṇaprasāda, ed. Skandapurāṇasya Ambikākhaṇḍah. Mahendraratnagranthamālā 2. Kathmandu: Mahendrasaṃskrțaviśvavidyālayạ̣, 1988.

Bisschop, Peter C. and Yuko Yokochi. The Skandapurāna. Vol. 4, Adhyāyas 70-95. Start of the Skanda and Andhaka Cycles: Critical Edition with an Introduction \& Annotated English Synopsis. In cooperation with Diwakar Acharya and Judit Törzsök. Brill: Leiden, 2013. 
Bisschop, Peter C. and Yuko Yokochi. The Skandapurāna. Vol. 5, Adhyāyas 96-112. The Varāha Cycle and the Andhaka Cycle Continued: Critical Edition with an Introduction \& Annotated English Synopsis. In cooperation with Sanne Dokter-Mersch and Judit Törzsök. Forthcoming. Boner, Alice. Principles of Composition in Hindu Sculpture. Leiden: E. J. Brill, 1962. Brockington, John. The Sanskrit Epics. Leiden: Brill, 1998.

Cozad, Laurie Ann. "Nāgas." In Brill's Encyclopedia of Hinduism. Vol. 6, Index, edited by Knut A. Jacobsen, Helene Basu, Angelika Malinar, and Vasudha Narayanan, 72-80. Leiden: Brill, 2015.

Deshpande, N. A. The Padmapurāna. Part 9. Delhi: Motilal Banarsidass, 1991.

Dokter-Mersch, Sanne. “Counter-Narratives: Parallel Themes in Śaiva and Vaiṣnava Mythology." PhD diss., Leiden University.

Gail, Adalbert. "Viṣṇu als Eber in Mythos und Bild." In Beiträge zur Indienforschung: Ernst Waldschmidt zum 80. Geburtstag gewidmet, edited by H. Hartel, 127-68. Berlin: Museum für Indische Kunst, 1977.

Gonda, Jan. Aspects of Early Viṣnuism, 2nd ed. Delhi: Motilal Banarsidass, 1969.

Granoff, Phyllis. "Saving the Saviour: Śiva and the Vaișnava Avatāras in the Early Skandapurāna." In Origin and Growth of the Purānic Text Corpus: With Special Reference to the Skandapurāna, edited by Hans T. Bakker, 111-138. Delhi: Motilal Banarsidass, 2004.

Harle, J. C. Gupta Sculpture: Indian Sculpture of the Fourth to the Sixth Centuries A.D. Oxford: Clarendon Press, 1974.

Jacobsen, Knut A. "Sacred Animals." In Brill's Encyclopedia of Hinduism. Vol. 1, Regions, Pilgrimages, Deities, edited by Knut A. Jacobsen, Helene Basu, Angelika Malinar, and Vasudha Narayanan, 711-18. Leiden: Brill, 2009.

Joshi, Nilakanth Purushottam. "Kușāṇa Varāha Sculpture.” Arts Asiatiques 12 (1965): 113-19. Keith, Arthur Berriedale. 1914. The Veda of the Black Yajus School, Entitled Taittiriya Sanhita. Part 2, Kānḍas IV-VII. Reprint, Delhi: Motilal Banarsidass, 1967.

Kintaert, Thomas. "On the Role of the Lotus Leaf in South Asian Cosmography." Wiener Zeitschrift für die Kunde Südasiens 54 (2011-2012): 85-120.

Kirfel, W. Die Kosmographie der Inder nach den Quellen dargestellt. Bonn: Kurt Schröder, 1920.

Lippe, Aschwin. "Early Chālukya Icons.” Artibus Asiae 34, no. 4 (1972): 273-330.

Lippe, Aschwin. Indian Medieval Sculpture. Amsterdam: North-Holland Publishing Company, 1978.

Meister, Michael. Encyclopaedia of Indian Temple Architecture: South India - Upper Drāvidadēśa - Early Phase, A.D. 550-1075. New Delhi: American Institute of Indian Studies, 1986.

Michell, George. Temple Architecture and Art of the Early Chalukyas: Badami, Mahakuta, Aihole, Pattadakal. New Delhi: Niyogi Books, 2014.

Mitra, Debala. "Varāha-Cave of Udayagiri: An Iconographic Study." Journal of the Asiatic Society 5, nos. 3-4 (1963): 99-103.

Nagar, Shanti Lal. Varāha in Indian Art, Culture and Literature. New Delhi: Aryan Books International, 1993.

O'Flaherty, Wendy Doniger. The Origins of Evil in Hindu Mythology. Berkeley: University of California Press, 1976.

Rangarajan, Haripriya. Varāha Images in Madhya Pradesh: An Iconographic Study. Mumbai: Somaiya Publications, 1997. 
Rao, T. A. Gopinatha. Elements of Hindu Iconography. Vol. 1, part 1. Madras: Law Printing House, 1914.

Saindon, Marcelle. Trois Manifestations de Vishnu, le Sanglier, l'Homme-Lion, le Nain: Les récits du Harivamsha. Paris: Presses de l'université Paris-Sorbonne, 2009.

Sharma, Preeti. "The Meaning and Symbolism of Varāha Motif: With Special Reference to the Chālukyan Rock-cut Caves at Bādāmī.” In Journal of History \& Social Sciences 1, no. 1 (July-December 2010), http://jhss.org/archivearticleview.php?artid=94.

Slaje, Walter. "Water and Salt (III): An Analysis and New Translation of the YãjñavalkyaMaitreyī Dialogue.” Indo-Iranian Journal 45 (2002): 205-220.

Snead, Stella. Animals in Four Worlds: Sculptures From India. Chicago: University of Chicago Press, 1989.

Soundara Rajan, K. V. Cave Temples of the Deccan. New Delhi: Director General, Archaeological Survey of India, 1981.

Sthapati, V. Ganapati. Indian Sculptures \& Iconography: Forms \& Measurements. Pondicherry: Sri Aurobindo Society, 2002.

Vaidya, Parashuram Lakshman. The Harivamsa, Being the Khila or Supplement to the Mahābhärata. Vol. 1, Critical Text. Poona: Bhandarkar Oriental Research Institute, 1969.

Vaidya, Parashuram Lakshman. The Harivamsa, Being the Khila or Supplement to the Mahābhārata. Vol. 2, Appendices. Poona: Bhandarkar Oriental Research Institute, 1971.

van Buitenen, J. A. B. The Mahäbhārata: 1. The Book of the Beginning. Chicago and London: University of Chicago Press, 1973.

van Buitenen, J. A. B. The Mahābhārata: 2. The Book of the Assembly Hall, 3. The Book of the Forest. Chicago and London: The University of Chicago Press, 1975.

van der Geer, Alexandra. Animals in Stone: Indian Mammals Sculptured through Time. Leiden: Brill, 2008.

Vogel, J. Ph. Indian Serpent-Lore or the Nāgas in Hindu Legend and Art. London: Arthur Probsthain, 1926.

Williams, Joanna Gottfried. The Art of Gupta India: Empire and Province. Princeton: Princeton University Press, 1982.

Willis, Michael. The Archaeology of Hindu Ritual: Temples and the Establishment of the Gods. Cambridge: Cambridge University Press, 2009.

Yokochi, Yuko. The Skandapurāna. Vol. 3, Adhyāyas 34.1-61, 53-69. The Vindhyavāsinī Cycle: Critical Edition with an Introduction \& Annotated English Synopsis. Brill: Leiden, 2013.

Zannas, Eliky. Khajuraho. 's-Gravenhage: Mouton \& Co Publishers, 1960.

Zimmer, Heinrich. Myths and Symbols in Indian Art and Civilization. New York: Pantheon Books, 1946.

\section{Online Sources}

American Institute of Indian Studies http://dsal.uchicago.edu/images/aiis/

GRETIL (Göttingen Register of Electronic Texts in Indian Languages) http://gretil.sub.uni-

goettingen.de

Los Angeles County Museum of Art http://collections.lacma.org

TITUS (Thesaurus Indogermanischer Text- und Sprachmaterialien) http://titus.uni-frankfurt.de 